\title{
ЛЕКСИКОГРАФСКО-ЕНЦИКЛОПЕДИЈСКЕ ОДЛИКЕ ПРОЗЕ РАДОВАНА БЕЛОГ МАРКОВИЋА
}

\begin{abstract}
У раду се указује на природу и одлике одредница енциклопедијског или лексиконског типа (у виду спискова) које се појављују у прози Радована Белог Марковића. Разматрајући посебно најфреквентније мотиве у његовим делима (смрт и њену естетику), осветљава се тзв. поменик, који као попис умрлих чини језгро његових романа и прича. Такође, пажња се посвећује оказионализмима (тзв. белизмима) који се појављују у виду предмета ван реалног света.

Кључне речи: одредница, енциклопедија, поменик, оказионализам, мистификација, дефинисање, каталог.
\end{abstract}

Упркос томе што се у прози Радована Белог Марковића све одвија у „временах помјатенију,”' као и у митопоетским просторима села Ћелија, Горње и Доње Псаче и Белог Ваљева, дакле, у измишљеним (раз)световима, али и у реалним који имају одлике измишљених, уочавамо да приповедач и у тој хаотичности успоставља некакав - особен, нехронолошки, неочекивани - ред. Тај сложен и занимљив задатак он реализује увођењем разнородних и посве необичних енциклопедијских одредница које често чине окосницу његових прича и романа. Оне су стваране искључиво с приповедачког аспекта, без лексикографске кодификације која је у појединим случајевима успешно

*ilisladja@gmail.com

1 Овај термин први пут приповедач је употребио у роману Лајковачка пруга (Марковић 2013/VI: 166). О специфичности лексике у прози Радована Белог Марковића, нарочито у вези са употребом неоархаизама, како их ауторка именује, писала је Милица Радовић-Тешић: „У нашем случају није реч о старом тексту, него о тексту писца који стандардни језик оплемењује стилски маркираном архаичном лексиком, покушавајући да је оживи, актуализује, активира. При таквом стилском квалифицирању управо настају за израђиваче описних речника истински проблеми и недоумице. Неоархаична лексика код савременог писца може бити не само преузета из старе епохе него врло често индивидуализирана, хибридна или онеобичена по моделу старог језика ... У таквом дискурсу она добија одређене стилизације - од ироничног, сатиричног до гротескног тона. Семантички миље је специфичан - реч је о судару двеју цивилизација - западне (аустроугарске) и источне (србијанске)” (Радовић Тешић 2009:179). 
примењена, али се углавном своди на описно-енциклопедијски начин дефинисања.

У овом раду, на основу неколико примера, представиће се типологија спискова Умберта Ека, као и карактеристикама тих специфичних одредница (Eko 2011).

Смрт и њена естетика, као најфреквентнији мотиви у прози овог писца, дати су у виду индивидуалних енциклопедија, тј. поменика. Попис умрлих Ћелијанаца језгро је приче Рещића читуљ $a^{2}$ и романа Лимунащија у Ћелијама. Попис умрлих Псачана представља језгро прича Дреје и рубине и Псачански мртваци (Живчана јапија). Попис умрлих геометара језгро је романа Кавалери старог премера итд. (Марковић 2013).

Одлика оваквих енциклопедија јесте референцијалност (Еко 2011: 12), jep се у њима приповеда о различитим световима (у прози Р. Б. Марковића увек их је више) и о различитим умирањима у оквиру тих светова. Иако приповедач добро познаје оно о чему приповеда (прилике у којима су јунаци живели и умирали, место и време њиховог живљења и умирања), нисмо у прилици да говоримо о потенцијалној довршености облика (Еко 2011: 15) због категорије коју испитује и која и њега, као и јунака приповедача, надилази.

У причи Рещића читуља и у роману Лимунација у Ћелијама, реч је о отвореним енциклопедијама, тј. о бескрајним списковима (Еко 2011: 3) зато што није могуће побројати смрти свих Ћелијанаца, нити свих Псачана, јер се оне с протицањем времена умножавају. Њих само тренутно бележи „мртвих душа поклисар" и њега ће, неминовно, заменити други када овај умре и када белешка о његовој смрти постане сегмент тог списка. Његов „посао” отежава и чињеница да неки од јунака чије смрти побројава и о којима сведено приповеда, умиру више пута. Немогућност коначног и суштинског поимања категорије смрти од стране јунака приповедача и од људи уопште, условљава настанак одредница, тј. набрајање појединачних смрти, јер је то покушај да се разматрана категорија учини делимично схватљивом. На основу наведеног закључујемо да и у Рещића читуљи и у Лимунацији у Ћелијама те енциклопедијске одреднице, тј. спискови, представљају варијащију на топос незрецивог (Еко 2011: 50).

Они су карактеристични по одсуству хронологије. На крају првог дела Ћелијанске читуле „мними литерата” (јунак приповедач) даје на знање да је читула измишљена и да је читав роман који приповеда (Лимунација у Ћелијама) његово „самоизмишљање”. Престанак „самоизмишљања”, било да је реч о читуљама или о роману, он изједначава с престанком његовог бивања.

Због немогућности потпуне „изрецивости”, као и због чињенице да се у оквиру те необичне енциклопедије сведено приповеда о више светова и о више смрти (некада и о више смрти једне те исте особе), оне имају и одлике поетских спискова (Еко 2011: 117). Њихова поетичност огледа се у бројним инверзијама на синтаксичком нивоу, као и на употреби поређења и метафора.

\footnotetext{
${ }^{2}$ Први пут објављеној у: Напред, год 42. бр. 1953 (27. 06. 1986, стр. 8); Ова прича није заступљена у оквиру сабраних дела Радована Белог Марковића (прим. аут).
} 
Они су истовремено и ризница архаизама (и застареле лексике), а у њима налазимо и оказионализме које Милош Ковачевић назива белизмима. ${ }^{3}$ Као пример наводимо један сегмент:

„Микаила светлица небеска по челу враштила, а сунце кад је изгрануло, као што то само сунце уме кад се свету улагује угледали су крај плота перунике, нежне и плаве, тамо где је земља само штир и лободу истурала, и сви су се уплашено међу се погледали: као да је неко нагло врата отворио" (Марковић 2013/VII: 18).

Они представљају и пример списка архаичних, готово заборављених имена, на пример: Хреља, Ефрем, Сандаљ, Властимир, Коцељ, Петрија, Косара, Дафина итд.

У оквиру наречених одредница налазимо и речи и изразе карактеристичне по специфичној звучности која доприноси изражајној вредности списка, тј. одредница у оквиру индивидуалних описних енциклопедија (Еко 2011: 118), на пример:

„Тари је ракљача у уво унишла. Кашику није, од тада, у руку узела. Кажу да Тара и није умрла, него да је у пољу изветрила!" (17)

Из перспективе аутора наведених читула, који се у прози Р. Б. Марковића јављају у различитим „појавима”, смрт је сагледана из мноштва перспектива, па отуда у исказима осим меланхоличности налазимо и низ иронијских отклона од смрти, аутоиронију када је реч о смрти, или смртима, јунака приповедача, дескрибовану ситуацијску комику и карневализацију. На пример:

„Када самоизмишљање доврши, и очи сведе, у Ћелијанску читулу и мними ће се литерата Р. Б. Марковић уписати. Он, за сада, још кашљуца над листинама Лимунације у Ћелијама и писмоношу погледа, почем га неко лудило гони да с ваљевском тајном полицијом једнострано корешпондује. Биће да му је ваљевска тајна полиција голему увреду нанела, понашајући се као да га нема.” (25)

У причи Дреје и рубине (Живчана јапија) налазимо скупину енциклопедијских одредница које чине попис, каталог, ствари псачанских мртваца. Тај каталог је такође једна врста поменика, тј. читуле, јер док се приповеда о стварима псачанских мртваца, приповеда се заправо о њиховим судбинама. Неке од њих су мистификоване, нпр.:

„Врх тамо Парамуна, видели па лажу, на једној букви виси официрски мундир, с девет од куршума рупа. Све су рупе дошле око срцета, и не може се рећи како су тукли а да не погоде; осим оног једног, из стрељачког строја, које се додељује пушка са ћоравим мецима".

У тим одредницама које нису хронолошки успостављене ни по редоследу рођења, а ни по редоследу умирања јунака, ипак уочавамо извесну хомогеност, јер заједничка карактеристика свих који се у њима спомињу јесте да су Ћелијанци и да више нису међу живима.

3 „Под белизмима, дакле, подразумијевамо неологизме као индивидуализме Белог Марковића. А најупечатљивији и најфреквентнији у дјелу Белог Марковића јесте реченични белизам везан за употребу лексеме тамо као јединице структурно-семантичког онеобичајења реченице, онеобичајења које јој даје статус неологизма" (Ковачевић 2015: 80). 
У већ помињаној књизи Р. Б. Марковића Живчана јапија, чија „необичност проистиче понајпре из жанровских недоумица", како је уочио Радивоје Микић, налазимо низ разноврсних малих енциклопедија, тј. енциклопедијских одредница које у целини чине садржај прича (Микић 2003: 251).

Један од примера индивидуалне описне практичне енциклопедије, тј. списка, у тој књизи јесте прича Псачанска дервеса. Њу чине описне одреднице појединих врста дрвета које расту у том митопоетском простору. Приповедач енциклопедиста описује њихову намену:

„Граничевина је најбоље дерво за сохе небеске, талпине и витлове воденичке, а и за вешала танка. [...] Шупља је буква за бадањ и за лужинску стабуљу. Леска је за притке и сплитање сепетинки. Валови се и сиротињске наћве у тополи дубе...” (13)

У тој књизи налазимо и мали, особен, лексикон псачанских анђела, односно страшила, у оквиру истоимене приче. ${ }^{4}$ Одреднице тог лексикона такође не подразумевају дефиницију него опис. Ти анђели размештени су „свуд по псачанским њивама”, а деца су их назвала „страшилима”. Увод у ту малу енциклопедију анђела, тј. страшила, јесте натуралистичка слика:

„Прекобројни тамо анђели бејаху размештени свуд по псачанским њивама. Стајали су на земљи право, као да су у њу пустили корење, али познало се да не могу даље да живе. Полако су се и тужно распадали - гледајући у свет не очима, него дупљама очију. Пред вече, око њих су се окупљала деца.

Звали су их страшила, а они су се, уистину, тако владали” (73: курзив изворни).

У оквиру сваке од одредница те енциклопедије приповедач се бави појединачним судбинама и интимним причама анђела (страшила):

„Рашчупани је коњаник, у конопљишту Леке Курјака, кажу, тешко крај с крајем састављао, под сивим и туробним небесима. Стајао је и гледао према ковачници, док су му се - испод усплахирене кабанице - помаљала дрвена ребра" (73).

Псачанска страшила се заљубљују, сањаре, рађају „страшиоца”. На основу те чињенице уочавамо да приповедач у очуђавању у свакој наредној одредници иде корак даље и да је сам списак чуда $a^{5}$ о којима поетски приповеда отворен тј. бескрајан (Еко 2011: 152):

„Милена Лукина је била једино женско страшило. Због ње су мушка страшила лако губила главу и улазила у свет чудесних тамо сањарија. У ноћима пуног месеца, у њеној би се близини често загрцнула хармоника, а Псачани би, с јесени, по овратинама и у разорима, наилазили на мала страшиоца, ситну неку људеж у дроњке одевену, чије су неприступачне очице светлуцале као зрнца соли, а дрвене ручице биле скрштене, некако молитвено, и увезане купиновом остругом. После се, веле, Милена Лукина повезала с господом у реденготима и цилиндрима, па су је из Чикића повртњака отпремили равно у Мусеум тамо ваљевски” (Марковић 2013/III: 74-75).

\footnotetext{
${ }^{4}$ Прича Страшила (први пут објављена у: Напред. Год. 47, бр. 2222 (23. 08. 1991, стр. 3), последњи пут је објављена у оквиру сабраних дела (Марковић 2013/III: 73-76).

5 „Списак чуда за модерног писца има чисто поетску функцију, он преузима древне податке знајући да спискови не упућују ни у шта постојеће и представљају искључиво имагинарне каталоге, у којима се може уживати само због њиховог flatus vocis” (Еко 2011: 155-156).
} 
О бескрајности каталога, тј. списка чуда сведочи и чињеница да приповедач, поред свега што је мистификовао, мистификује и јунаке - страшила која носе имена већ познатих књижевних јунака из дела других писаца. Њихова мистификација огледа се у томе што судбине јунака у тој причи сличе њиховим судбинама у „матичним” делима. У функцији те мистификације приповедач се служио гротеском:

„Кад је оно, осим задње њиве, пропио све што је икако могло да се пропије, рођак Радисав није у надницу пошао, по туђим њивама, него се приволео последњој својој прљужи, нешто већој од таксене марке, и примио се да на њојзи буде страшило. С муштиклом од трешњева прута, несвестан да носи име трагичног јунака из познатог романа, седео је поваздан на пласту сена. Десном је руком показивао путеве птицама, а левом се придржавао за колац, мада само овлаш. Једног јутра, затекли су га на том коิцу натакнутог” (Марковић 2013/III: 75-76).

Сада ћемо се детаљније позабавити и једним целим поглављем књиге Живчана јапија. Оно се састоји од деветнаест кратких прича, чији је наслов Урутке и сокоћала, а које има све одлике списка чуда (Еко 2011: 153). Ту налазимо оказионализме, као одредничке речи са дефиницијом и описом својственим енциклопедијском обрађивању лексике.

С обзиром на то да је реч о списку чуда, одмах ћемо узети у обзир и то да је он имагинаран (Еко 2011: 153), као и то да је његова функција поетска. Необична збирка састоји се од разноврсних алатки (урутка - оно што може да се узме у руку) и направа, машина (сокоћала), које су измишљене, које не постоје у реалном свету. Оне су функционалне само ван тог света, дакле у просторима „разсвета” и „развремена”.

Уколико бисмо испитивали историју настајања те необичне енциклопедије, свакако бисмо закључили о радозналости приповедача и његовој страсти писања, стварања одредница, тј. измишљања и оригиналног именовања необичних, чудноватих предмета (Gob-Druge 2009: 16), као предмета који не постоје у реалном свету: ћусек - сокоћало за хватање паре из вампирског срца (97); кланцара - дође као мишоловка сандучара, само што служи за хватање снова (98); смичка - урутка за вађење душа (101); дорожма - узица илити сиџимка, за спуштање у бунар сећања (114).

За разлику од стварних, реалних енциклопедија, у којима су начела разврставана, очувања и јавног значаја јасна (Валери 2010: 132), када се посматра ова енциклопедија, морали бисмо се замислити над сваким од тих начела и уочити да она зависе од перспективе читаоца.

Начело разврставања одредница у оквиру те енциклопедије било би непостојање описаних предмета, њихова необичност, зачудност, као и необичност и зачудност њихове намене. Наиме, што су нестварнији то су постојанији из перспективе читаоца из овостраности, тј. реалног читаоца, зато што отварају бесконачан простор за имагинацију. Самим тим, та енциклопедија је отворена, може да се дописује.

Када је у питању та енциклопедија, начело њеног јавног значаја потпуно је ирелевантно, готово апсурдно, зато што из перспективе читаоца који припада овостраности, она испуњава само једну, а можда и једину функцију 
- уметничку - и апстрахује потенцијално постојање било које друге функције. Уколико је тако, због зачудности њених одредница и једине наведене функције, она отвара бесконачне могућности имагинирања читаоца који није оптерећен ничим што не припада сфери уметничког.

У оквиру истог поглавља Урутке и сокоћала уочавамо још једну мистификацију. Аутор баш у оквиру њега смешта различите врсте одредница о мнимим бићима - гиштовима - карактеристичним само за његову прозу. Проучавајући детаљно одреднице тог појма у више прича које поглавље садржи, али и у другим делима Р. Б. Марковића, уочавамо да је функција тог поступка додатно мистификовање већ мистификованих бића, увођење самог текста у просторе фантастике и релативизација тих бића као пример релативизације свега у свету прозе овог писца, али и у свету уопште.

Наиме, осим што на самом почетку прве описне дефиниције одреднице приповедач каже да гишт није ни урутка ни сокоћало, у некој другој да су гиштови мнима бића лајковачке досаде и уске пруге, у некој трећој причи он каже да гиштови постоје тако што не постоје.

И у вези с тзв. мнимим бићима - гиштовима - о којима су у различитим причама писане специфичне (описне) одреднице у оквиру Живчане јапије, и не само у оквиру ње, потврђујемо изразиту особеност приповедачког поступка Р. Б. Марковића коју смо већ раније уочили. Код њега је очуђавање (офантастичавање, мистификација) увек прогресиван процес који се градацијски развија. Он усложњава тај процес тако што додатно мистификује оно што је већ мистификовао.

По својој природи већ фантастична бића, гиштови, у његовом делу очуђавају се неколико пута и често је нова мистификација сложенија од претходне или је пак у потпуности - садржајно - различита од ње. Како би се та карактеристика у потпуности увидела, навешћемо избор одредница које „дефинишу” те појмове. Те одреднице их заправо увек релативизују, иако бисмо очекивали да их прецизно дефинишу. Функција тог поступка јесте да се укаже на релативност свега, па и сваког појма који се ,дефинише” у прози Р. Б. Марковића:

1. „Ни урутка ни сокоћало, гишт је морти намисао каква, с којом се немоћно батргају они који замишљају да лепих ће дана још бити, иако је и псачански богомољац Врлоје у ћошак бацио ружине бројанице и примио кључе задружног за коже и шишарку тамо магацина".

2. „Неее! - не могу се за гиштове примити они пред очима светлаци, док те у псачанском мраку шамаришу”.

3. „Због гиштова, забун-књиге кажу, неће па неће сан на очи ни поп Величковој на страни воспитаној шћери, а кад би заспала - ракију би јој под нос наносили, одољен траву, ма и прекоморске неке шпеције, еда јој се, у сну, надвоје-натроје не раседне душа, почем се видело, док спава, да чудно и замишљено спава и дајој се некако заноси на јастуку глава, као у неког за ког се не зна да л’ прездравља ил' се разболева” (курзив изворни) (116-117). 
Да приповедач остаје доследан у намери да већ мистификовано мистификује доказ је и прича која следи одмах након приче Гиштови, а чији је наслов Исто само друкчије (118). Дакле, приповедач већ различито описан појам из претходне приче описује и у овој, али сасвим другачије. Обрађене одреднице изгледају овако:

1. „Осванути нећеш с оним гиштовима с којима си омркнуо, иако кажу да гиштови нису подложни променама времена и годишњих доба, нити упливисању оног ко на престолу жуљи гузицу, па се заиста свако паметан насмејати мора штокаквом свату који, у души каква разура кад му избије, мисли да ће се и гиштови на супроћене орте разројити, каоноти псачанске партаје - око питања: Може ли се под старим кметом нови живот засновати?

2. Најпосле, гиштови се и не питоме у душама које се вију под стрехама убогих псачанских колиба, но у душама оних који већма бораве у некаквом осим света свету, где и њихови су покојници живи, па се, из тог осим света, ти и такви ретко и накратко повраћају, можда два-трипут на годину ради преобуке, а понеко и зато што је на попову ћерку бацио око, али ће беспотребно на гиштове кривицу сваљивати раскукана својта оног ко увиди да узалуд је млад ако капу пред псачанским пандуром скида, па заборави да, једном у сто година, и у рукама таквог никоговића са̂ма од себе пукне пушка" (курзив изворни).

Примере „дефинисања” гиштова налазимо и у другим делима овога писца. У роману Лајковачка пруга наслов једног поглавља је Лајковачки гиштови (56). То поглавље такође је известан списак одредница у којима је различито дефинисан појам гишт. Ми их не можемо садржајно довести у везу са већ наведеним описима (одредница) из прича у оквиру Живчане јапије. Оно што им је заједничко, што је њихов најмањи, али значајан садржалац, јесте фантастичност. Други значајан садржалац им је хумор који се заснива на иронији и аутоиронији (приповедач говори о себи у трећем лицу).

Хумор није карактеристичан за све одреднице, али уочавамо његову честу употребу. Како бисмо то показали, навешћемо тек пар примера из тог романа, с тим што напомињемо да све наведено важи и за бројне одреднице нареченог појма и у другим романима Р. Б. Марковића:

1. „Гиштови су, према нотама, мнима бића лајковачке досаде и меланхолије уске пруге. / Многи верују да су се први гиштови између два рата јавили, у лајковачкој читаоници, али то сигурно није истина. Када су први гиштови примећени, Лајковчани су били далеко и од помисли на утемељене читаонице. [...]

2. А гиштови су незаобилазна стварност постали тек кад је са званичног места речено да су вештачки и измишљени. 
Ти спискови би се могли именовати као - барокни - каква је, заправо, по суштинским карактеристикама, књижевност Р. Б. Марковића и какав је, како смо само на основу примера који су заступљени у овом раду имали прилике да видимо, његов језик. По тој особини, он је такође јединствен у оквиру целокупне савремене српске књижевности. Идеја о барокности тих одредница, као и других у његовој прози, јесте чињеница да су они „енциклопедијске структуре” (Еко 2011: 233), као и да се у њима набрајају „бескрајна својства” (Еко 2011: 233). Те спискове бисмо, по класификацији Умберта Ека, могли назвати тезаурима. ${ }^{6}$

Само на основу овде побројаних и наведених примера који говоре у прилог тврђењу да су каталози Р. Б. Марковића тезаури, уочавамо зашто му у оквирима српске књижевности припада посебно место и зашто је за проучавање подједнако привлачан и језичким и књижевним стручњацима. Можда је ово лепа прилика да наведемо да је временски распон - по годинама рођења - између најстаријих његових проучавалаца и најмлађих 60 година.

\section{ЛИТЕРАТУРА}

Валери 2010: П. Валери, Проблем музеја, Београдски књижевни часопис 19, Београд, 132, из: Paul Valery, „Le problème des musées” (Le Gaulois le 4 avril 1923; прештампано у Oeuvres, tome II, Pièces sur l'art, Gallimard, Bibliothèque de la Pléiade, 1960, pp. 1290-1293).

Илић, Слађана (2012): „Бескрајни спискови у прози Радована Белог Марковића", у Вељкови дани 2011: Кюижевни погледи Вељка Петровића; Кюижевни портрет Радована Белог Марковића: зборник саопштења [уредник Радивој Стоканов], стр. 94-106. Сомбор: Вељкови дани и Градска библиотека „Карло Бијелицки”.

Ковачевић 2015: М. Ковачевић, Стилематичност реченице Радована Белог Марковића, у: Р. Микић (ур.), Интерпретације у Ћелијама: проза Радована Белог Марковића: зборник радова са научног скупа о прози Радована Белог Марковића, о Крстовдану, 27. септембра 2014. године у Ћелијама, Лајковац: Градска библиотека Лајковац, 73-138.

Марковић, Бели Радован (2013): Сабрана дела, књиге 1-13. Лајковац: Градска библиотека.

Микић 2014: Р. Микић, Прича и мит о свету: огледи о прози Радована Белог Марковића, 2, допуњено изд. Београд: Албатрос Плус.

\footnotetext{
${ }_{6}^{6}$ „Тезауро разрађује идеју о Категоричком индексу, некој врсти големог речника с тим што би од речника имао само спољни изглед, с обзиром да је количина својстава које излаже таква да наводи на помисао како се не ограничава само на она која су поменута. Са барокним задовољством због чудесног проналаска он свој индекс представља као 'тајну која је заиста тајна', рудник бескрајних метафора и домишљатих појмова" (Еко 2011: 233).
} 
Микић 2003: Р. Микић, Приповедна јапија и њена подлога, предговор у: Радован Бели Марковић, Живчана јапија, допуњено и „углађено” издање, Београд, 251.

Радовић Тешић 2009: М. Радовић Тешић, С речима и речником, Београд, Учитељски факултет.

Gob, Druge 2009: A. Gob, N. Druge, Muzeologija: istorija, razvoj i savremeni izazovi; prevela s francuskog Vesna Injac. Beograd: Clio и Народни музеј. Eko, Umberto (2011): Beskrajni spiskovi (Umberto Eco, Vertigine della lista, 2009), с италијанског превео Александар В. Стефановић. Београд: Плато.

Slađana L. Ilić

\author{
LEXICOGRAPHIC AND ENCYCLOPAEDIC FEATURES OF RADOVAN \\ BELI MARKOVIĆ'S PROSE WORKS
}

(Summary)

All works of Radovan Beli Marković are distinguishable for the following storytelling devices: his transposing of the story from the realm of reality to the realms of grotesque humour, meditation or fantasy; the introduction of lyrical and naturalistic elements in storytelling; a fusion of the lyrical and the narrative; the employment of various types of infinite and finite lists (determinants that often underpin his short stories and novels, created exclusively as storytelling devices, without any lexicographic codification, which, while used to great effect in some cases, is mainly reduced to a descriptive, encyclopaedic defining tool) etc. We found the latter aspect to be of particular interest, and our conclusion based on research is that the lists, or rather encyclopaedias, in his short stories and novels are in fact thesauruses exuding a baroque quality, written in an idiosyncratic lect (while the author has used all varieties of Serbian, he is also a masterful linguistic innovator who skilfully coins neologisms, the most common and most unusual of which are his occasionalisms (termed Belisms by professor Miloš Kovačević, PhD)). All of this is employed to convey the atmosphere of "perturbed times" and demonstrate how fluid the boundaries are between different worlds - real, possible and impossible ones. In view of these facts, our conclusion after a thorough examination of the author's prose is that we have succeeded in uncovering here but one of its facets for the researchers of his work; however, this paper also provides a great impetus for further research by both literary and linguistic experts, as well as by those who specialise in rhetoric, stylistics and semantics, as the author, most notably when using the lists featured in his prose works, non-chronological though they may be, establishes an order characterised by exquisite aesthetics, polysemy and the truth of being. 